\title{
Suitability Assessment of groundwater and soils contamination from Automobile Junk Waste (South-east Nigeria)
} UCHE O. CHUKWURA ${ }^{1 *}$ AND OGBONNAYA IGWE

${ }^{1}$ Department of Geology, Faculty of Physical Sciences, University of Nigeria, Nsukka

(*correspondence:ogugua.chukwura.pg79992@unn.edu.ng)

Automobile junk market in a densely populated slum located in Obosi and housing estate in Onitsha, Anambra State, South-East Nigeria was used for hydrogeochemical studies. There are evidence of pollution due to industrial waste accumulation, and domestic waste discharges channeled directly with or without treatment into the surrounding area. Water in the study area is not potable and previous studies were limited to geochemical assessment. The aim of the study was to examine the level of the heavy metals and biological contaminants within the study area. Intensive field sampling and monitoring was conducted on forty (40) groundwater and fourteen (14) composite soil sample were collected at depth $0-15 \mathrm{~cm}$ and $15-30 \mathrm{~cm}$. Analysed physicochemical parameters in the dry and wet seasons inferred that the groundwater are slightly acidic to neutral, soft to mdoerately hard when compared with the World Health Organization maximum allowable concentration values and the Nigerian Standards for Drinking Water Quality. Some toxic and trace elements $(\mathrm{Fe}, \mathrm{Cu}, \mathrm{Ni}, \mathrm{Zn}, \mathrm{Mn}, \mathrm{Pb}$ and $\mathrm{Cd})$ were found to be more than the permissible levels for drinking water on regulatory standards. There was absent of feceal but lower count $\left(1.0 \times 10^{2}\right.$ to $\left.2.5 \times 10^{3} \mathrm{cfu} / \mathrm{ml}\right)$ of total coliform. Higher heavy metals content in $\mathrm{ppm}(\mathrm{Pb}$ and $\mathrm{Cd}$ varied 0 to 1.80 and 0 to 7.38 respectively, and $\mathrm{Fe}, \mathrm{Cu}, \mathrm{Ni}$, $\mathrm{Cr}, \mathrm{Zn}, \mathrm{Mn}$ with highest nickel concentration) was found in the soil (and permeable). Metal concentrations were found in the groundwater in the following order: $\mathrm{Ni}>\mathrm{Pb}>\mathrm{Cd}>\mathrm{Fe}>\mathrm{Cu}>\mathrm{Mn}>\mathrm{Cr}>\mathrm{Zn}$. Statictical results gave significant diffrences (at 0.05 ) between $\mathrm{EC}$ and nitrate, EC and $\mathrm{TH}, \mathrm{BOD}_{5}$ and $\mathrm{DO}$, and several other elements. The Contour maps for the trace elements displayed the spatial distribution (pollution pattern) and point source of contaminants. PHREEQC geochemical thermodynamic modelling was use to predict the minerals present. The study aids in the understanding of the chemistry of groundwater for long monitoring and management for the local community. 